\title{
Analysing the Role of Framework Conditions Influencing International Entrepreneurial Opportunity Identification Process
}

\author{
Yonni Angel Cuero Acosta, Richard Adu-Gyamfi, Md. Noor Un Nabi, Utz Dornberger
}

\section{A B S T R A C T}

Objective: The objective of this paper is to determine and analyse the framework conditions that influence the entrepreneurial opportunity identification and action in the international market context.

Research Design \& Methods: Scholars from the International Business and International Entrepreneurship (IE) research fields agree that the process of internationalisation is triggered by opportunity identification. The extant literature is reviewed by assessing the framework conditions that domestic and international markets offer for entrepreneurial actions. An analytical juxtaposition of the influential factors is conducted in the light of various stages of the opportunity identification process by examining at each stage - possible effects of domestic and international market context.

Findings: This paper brings into the IE discussion a conceptual matrix of various elements and factors - external conditions - which influence the creation of nexus by entrepreneurs to the markets.

Implications \& Recommendations: The conceptual matrix offers new insights for theoretical development and arguments for designing empirical research in terms of external conditions. It is expected to provoke more theoretical and practical questions from scholars within the IE field.

Contribution \& Value Added: The originality of this work lies in proposing a comprehensive framework to understand how context interacts with the entrepreneurial opportunity identification process.

\section{Article type: conceptual paper}

Keywords: international entrepreneurial opportunity process; market context JEL codes: $\quad$ F23, M16

\section{Suggested citation:}

Cuero Acosta, Y.A., Adu-Gyamfi, R., Nabi, M.N.U., \& Dornberger, U. (2017). Analysing the Role of Framework Conditions Influencing International Entrepreneurial Opportunity Identification Process. Entrepreneurial Business and Economics Review, 5(3), 9-29. http://doi.org/10.15678/EBER.2017.050301 


\section{INTRODUCTION}

The theory and practice of international business (IB) and entrepreneurship recognise the critical role of the entrepreneur in the successful internationalisation of the firm (McMullen \& Dimov, 2013; Oyson \& Whittaker, 2015). These domains have been theoretically and methodologically integrated by forming the field of international entrepreneurship (IE) (Allen, 2016; McDougall \& Oviatt, 2000). Authors in the IE field have widely researched the entrepreneur's pursuit of conducting cross-border activities and competing in markets (Schweizer, Vahlne, \& Johanson, 2010). In this regard, entrepreneurial action fosters cross-border activities by combining individual as well as firm-level capabilities. IB and IE fields agree that the process of internationalisation is triggered by the entrepreneurial opportunity process, which is also the starting point and the core of the conceptualisation of entrepreneurship (Shane \& Venkataraman, 2000).

The concept of opportunity identification in international entrepreneurship has generally focused on the sources of opportunities (Eckhardt \& Shane, 2003), entrepreneurs' approach to opportunity exploitation (Sarasvathy, 2001), and the discovery of opportunity (Alvarez \& Barney, 2007; Andersson \& Evers, 2015; Busenitz, Plummer, Klotz, Shahzad, \& Rhoads, 2014; Muzychenko \& Liesch, 2015). These issues together constitute the individual-opportunity nexus in entrepreneurship (Davidsson, 2015; Shane \& Venkataraman, 2000). Likewise, these topics have contributed greatly to strengthen the conceptualisation of opportunity as a process applied by entrepreneurs in the quest for initiating a venture (Davidsson, 2015). However, opportunities do not just come from entrepreneurs' impetus (Wood \& McKinley, 2010). Entrepreneurs are constantly faced with challenges due to fastpaced changes in customer needs and preferences or production patterns (Hernández, Martínez Piva, \& Mulder, 2014). These challenges come from financial volatility on markets, rapid technological innovation, changing customer preferences, the growth of new segments on the market, culture, demographic rates, institutional framework conditions, macroeconomic conditions, and the natural environment (Davidsson, 2015; OECD, 2016). Recently, Davidsson (2015) has combined these factors under the label external enablers. This reflects the ever-increasing level of dynamism in the market conditions. This implies that an opportunity does not only emerge from the individual mindset, but can also have its origin in the external environment in which the entrepreneur operates (Davidsson, 2015). If one takes the context of IE, this dimension necessitates a more detailed conceptual exploration to examine how entrepreneurs deal with these external enablers. Particularly, the connection between the individual level and the external enablers' level elicits two conceptual enquiries: Do entrepreneurs apply a different kind of approach to identify entrepreneurial opportunity in a different market context? Do the domestic or international market contexts play a differentiating role in the decision-making process of entrepreneurs?

To address these enquiries, this paper is devoted to a conceptualisation of the opportunity recognition by entrepreneurs in different market contexts i.e. domestic and international. The answers to these questions will contribute to the IE scholarship with new insights about the role played by certain external factors, which push entrepreneurial action through the process of opportunity recognition. Thus, this paper aims to determine the framework conditions that influence the process of entrepreneurial opportunity identification in the international market context and analyses how such framework conditions play their role in this process. 
The paper is organised as follows. The introduction presents the concept of this paper. Then, the materials and methods section explains how the revision of the literature was conducted in order to theorise the entrepreneurial opportunity concept. Next, the literature review describes the logic of argumentation that we follow to build the conceptual framework of the entrepreneurial opportunity identification as a process. We further define what constitutes the domestic and international market contexts. The factors influencing the entrepreneurial opportunity identification process in the domestic and international market contexts are also discussed. We finalise this paper by concluding and giving some remarks for future research.

\section{MATERIAL AND METHODS}

This paper is predominantly based on the review of literature from the relevant areas of entrepreneurship research. Specifically, the IE domain provides a conceptual framework by emphasising the international entrepreneurial opportunity process. Hence, the major contribution of this paper is the creation of a conceptual framework in order to rationalise the role of external factors on the entrepreneurs' opportunity recognition process. In order to review the literature, the authors identified works about the entrepreneurial opportunity concept. Limiting the search to the concept of entrepreneurial opportunity allowed the researchers to have an overview of the conceptualisation of the role of the market context regarding the opportunity process. The search was limited to scientific literature focussed on articles from peer review journals. This search was conducted using major entrepreneurship research academic databases, such as Proquest, EBSCO Host, and JSTOR. Equally, important, academic browsers such as Science Direct, SpringerLink, and Google Scholar were used. The search was established without limiting the period of publication. This allowed the researchers to track the origin of the discussion about the opportunity concept in the areas of entrepreneurship and international business.

Secondly, once the most important stream was identified within the entrepreneurial opportunity concept, the following keywords were used, i) entrepreneurial opportunity (13 papers), ii) opportunity identification (12 papers), iii) opportunity recognition (14 papers), and iv) international entrepreneurial opportunity and opportunity development process (19 papers). These papers were identified within the domains of IE, international business, entrepreneurship and strategic management. Thirdly, the analysis of the extant literature focused on those papers, which discuss the issue of the external environment, external enabler, business environment, and framework conditions (11 papers). These papers are listed in the reference section. Finally, we narrow the discussion to those papers, which focus on the aim of the study.

As a result of this conceptual in-depth analysis, we propose a comprehensive matrix in order to analyse the decision phases through which entrepreneurs go when identifying a viable entrepreneurial opportunity.

\section{LITERATURE REVIEW}

IE is a well-established academic domain (Coviello, McDougall, \& Oviatt, 2011; Dimitratos, Buck, Fletcher, \& Li, 2016). It has been a flourishing field that has contributed to expanding the discussion on entrepreneurship. IE is the result of a cross-disciplinary research into 
international business and entrepreneurship (Allen, 2016; Coviello et al., 2011; McDougall \& Oviatt, 2000; Ngo, Janssen, \& Falize, 2016). Authors point out that the IE domain has particularly paid attention to topics such as entrepreneurial internationalisation of ventures, international comparisons of entrepreneurship, and comparisons across countries or cultures. Within these topics, various issues have been studied, such as venture type, internationalisation, networks and relationships, internationalisation patterns and process, and organisational issues, among others (Jones, Coviello, \& Tang, 2011). IE does not only cover topics related to internal aspects of the firm but also how entrepreneurs interact with external factors, such as the dynamics of international markets. In this sphere of analysis, the study of networks has provided the backdrop to analyse opportunity recognition (Ardichvili, Cardozo, \& Ray, 2003; Mainela, Puhakka, \& Servais, 2014).

Researchers from different schools of thoughts agree on the relevance of opportunity to foster entrepreneurial action (Chandra, Styles, \& Wilkinson, 2015; Greblikaite, Sroka, \& Gerulaitiene, 2016; Grégoire \& Shepherd, 2012). "Without an opportunity, there is no entrepreneurship" (Short, Ketchen, Shook, \& Ireland, 2010, p. 40). While IE and entrepreneurship scholars agree with the statement, a consensus on the ontological foundations of the concept of opportunity is yet to come. Somehow, either the ontological discussion about the opportunity concept or related elements to exploit an opportunity have drawn attention in the academic community.

Opportunity is at the core of every entrepreneurial initiative (Short et al., 2010). "Entrepreneurs develop business opportunities to create and deliver value for stakeholders in prospective ventures" (Ardichivili et al., 2003, p. 113). In this sense, it is the exploitation of an opportunity, which allows the entrepreneur to fit their value propositions to an unsatisfied need on the market. Based on the seminal works of Schumpeter (1934), Kirzner (1973) and Casson (1982), Ardichvili et al. (2003) pointed out that opportunities help to meet market demand through the combination of resources by entrepreneurs. Hence, from the entrepreneurship perspective, an opportunity is the result of how entrepreneurs combine resources and capabilities that are at their disposal (Mary George, Parida, Lahti, \& Wincent, 2016; Shane \& Venkataraman, 2000; Wood \& McKinley, 2010). What is also needed is to differentiate a daily-basis chance of doing business from one new product or new services to be delivered to the market, which can originate a new venture. Being more specific, the entrepreneurship theory explains an entrepreneurial opportunity as a concept which is defined as a set of circumstances "in which new goods, services, raw materials, markets and organising methods can be introduced into the formation of new means, ends, or means-ends relationships" (Eckhardt \& Shane, 2003, p. 336). It is important to highlight that exploitation of an opportunity represents the offer of newness. Thus, entrepreneurial opportunity ${ }^{1}$ is understood as "an entrepreneurially discovered or created situation in which new goods, services, raw materials, markets and organizing methods are conceived as having a potential for exploitation through entrepreneur-led action to form and transform them into new means, ends, or means-ends relationships" (Oyson \& Whittaker, 2015, p. 309). The concept of opportunity itself has emerged as a pivotal entrepreneurial factor which covers the novelty of entrepreneurial ideas according to the classic perspective, such as the one posted by Schumpeter (1934). Given the argument, it is necessary to review this concept against the backdrop of the international market context.

\footnotetext{
${ }^{1}$ Hereafter, in our discussion we are going to interchangeably use the term opportunity and entrepreneurial opportunity.
} 


\section{Opportunity Identification in the International Context}

It is highlighted that the entrepreneurial opportunity identification process adopts new elements when this process is developed to make full use of an international set of favourable circumstances (Alvarez, Barney, \& Anderson, 2013; Chandra et al., 2015). Authors have coined this process as international opportunity identification, defined as "the recognition and exploitation of entrepreneurial opportunity that leads to new international market entry" (Chandra, Styles, \& Wilkinson, 2009, p. 31). Muzychenko and Liesch (2015) add more elements by defining an international opportunity as "the likelihood of conducting an exchange with new or existing partners, such as foreign intermediaries of foreign customers, in new international markets" (Muzychenko \& Liesch, 2015, p. 705). This conceptualisation of an opportunity in the international market gives an idea that antecedents of entrepreneurial opportunity identification are likely to differ in their compositions and effects according to the market context. Such differences are expected to be more prominent when the entrepreneur's opportunity identification efforts are compared between the international and domestic market context. From the individual level perspective, it is possible to note the significance of social capital as a crucial factor in order to facilitate the way to locate the context for business ideas. That is to say, entrepreneurs may use their social capital when deciding to target domestic or international markets. For instance, this is possible by identifying international opportunities through personal contacts (Oyson \& Whittaker, 2015). Additionally, key issues related to the opportunity identification process in international markets are entrepreneurial cognition, prior knowledge, and industry context. However, from the conceptual point of view, the logic of the interplay among such factors should be clarified. These elements neither interact nor influence the opportunity identification process by a linear sequence. Therefore, it is necessary to understand the logic of their interplay as antecedent to the entrepreneurial opportunity identification process. Furthermore, factors such as culture and the impact of institutions should be part of the analysis to widely grasp the entrepreneur vision to select markets. In other words, external enablers are needed as part of the opportunity process. To have a better picture of which factors affect the process, it requires from us to observe the structure of the opportunity identification process itself.

\section{Unbundling the Entrepreneurial Opportunity Identification Process}

Understanding opportunity - as a vital factor within entrepreneurial activities - the conceptual discussion in the literature has turned into the debate as to whether entrepreneurs identify or recognise opportunities (Alvarez et al., 2013; Andersson \& Evers, 2015; Ardichvili et al., 2003; Chandra et al., 2009; Chandra et al., 2015; Eckhardt \& Shane, 2003; Heilbrunn, 2010; Mainela et al., 2014; Mary George et al., 2016; Oyson \& Whittaker, 2015; Shane, 2000; Vaghely \& Julien, 2010). This peculiar debate is quite important due to the need to capture the process itself. As a dominant paradigm, the entrepreneurial opportunity is seen as a construction of the entrepreneur (Shane \& Venkataraman, 2000). As many scholars explain, entrepreneurs develop opportunities starting from a simple scratch of business ideas, evolving into a business model, and executing a business plan (Dornberger \& Suvelza, 2012). Ardichvili et al. (2003) argued that the recognition of opportunities by entrepreneurs is part of the whole opportunity identification process and not an extra one. Given these facts, the authors 
have agreed that the core of the opportunity identification process is made up of the following stages: being alert (which has been studied under the concept of entrepreneurial alertness), search for information and evaluation, and construction of the opportunity (Mary George et al., 2016). These three main stages are conducted by entrepreneurs in order to develop/exploit an opportunity (Oyson \& Whittaker, 2015).

Entrepreneurial alertness: This implies that there are persons who are more sensitive to the needs that a market can offer (Gaglio \& Katz, 2001). Individuals sense the needs of the market and propose new ways to satisfy those needs by creating value (Mary George et al. 2016). Alertness is conceptualised as a mediator between the personal features of an entrepreneur and the birth of a new venture (Sambasivan, Abdul, \& Yusop, 2009). Entrepreneurs combine their expertise with managerial abilities to not only identify but also develop an opportunity. Alertness as a major entrepreneurial characteristic interacts with other factors. Indeed, the interplay among other factors, such as cognition, prior knowledge, social network, and the abilities of entrepreneurs make it possible to clarify the opportunity and their scope (Webb, Ireland, Hitt, Kistruck, \& Tihanyi, 2011). In identifying and exploiting an opportunity, an individual's capabilities, as well as personal characteristics, such as entrepreneurial alertness, make the difference between those alert and non-alert individuals.

Search: Once an individual observes and understands the opportunity and the chance that they possess to exploit it, they continue with the search of information. This is the search, which allows entrepreneurs to use all their sources of knowledge. However, to limit the information which can be found, entrepreneurs establish criteria to narrow the search (Fiet, 2007). In this regard, it is crucial for individuals to systematise their knowledge in a way which will facilitate the identification of opportunities (Muzychenko \& Liesch, 2015). While looking for opportunities, entrepreneurs explore their surroundings to have a clear idea of what can match the needs that they observe. This is helpful to create value and configure new venture characteristics. This also means that the systematic search of information should be accompanied by the evaluation of the information and opportunity itself. Systematic search gives the occasion for individuals to assess the scope of the opportunity and the capacity of their proposed venture to fit that opportunity.

Evaluation: This is an important part of the opportunity identification process (Ardichvili et al., 2003). This evaluation can be applied in a formal, systematic, or an informal way. It implies how the identified opportunity has been located into the business concept, how the value offered through the business model is going to be assessed by the customer, and how the new product or the new processes are conceived. It is important to understand how the value created to exploit a business opportunity is going to generate gains for the entrepreneur. Therefore, value creation has to be evaluated at each moment. Equally important is the evaluation of resources, which are needed to develop the opportunity on the international market. The evaluation within the stages is important in order to continue developing the business idea. In order to recognise an opportunity and develop it into a business concept, the evaluation of the feasibility of that opportunity-focused business model is required. This business model serves as a guide for the exploitation of entrepreneurial opportunity in the subsequent phases (Chandra et al., 2015).

Construction: Scholars relate this stage to the recognition of an opportunity (Eckhardt \& Shane, 2003). Ardichvili et al. (2003) pointed out that in this stage the entrepreneur first 
senses the needs that exist within a market or identifies resources that have not been used yet. Secondly, the entrepreneur visualises the fit among market needs and resources deployed to satisfy those needs. Third, the entrepreneur converts that fit into a business concept. This stage is subdivided into smaller steps, which an entrepreneur can develop through his or her own capabilities and the configurations of resources and business. This match among the needs, resources, and the way in which the entrepreneur plans to solve those market needs is called the fit, which is also associated with the discovery of a business opportunity (Shepherd, Williams, \& Patzelt, 2014). We argue that entrepreneurs mentally construct their business ideas. Once this mental construction is elaborated, they proceed to exploit the business opportunity identified.

Exploitation: This stage consists of various processes which entrepreneurs can develop to materialise business ideas. This can include - but not limited to - the development of new products, new processes, the proposal of a new business model, and the creation of a business organisation (Short et al., 2010; Vaghely \& Julien, 2010). This requires proactive, risk-taking, and innovative entrepreneur's characteristics which entrepreneurs can exert through their entrepreneurial orientation (Anderson, Kreiser, Kuratko, Hornsby, \& Eshima, 2015). In this sense, developing an identified opportunity requires internal as well as external sources of resources. The exploitation - that we argue can be conceptualised at this stage - implies how the entrepreneurs are going to make the identified opportunity and its development profitable (Oyson \& Whittaker, 2015) and how the business model created to fit market needs and resources is going to offer a value for customers. Value serves as an engine for the entrepreneurial spirit and it is the meeting point between customers and the entrepreneur's business ideas.

The stages mentioned above are the core of the identification process. Entrepreneurs implement these stages in order to be able to materialise the chance that they find among the imperfections of the markets. Conceptualising this process in this way, where entrepreneurial alertness is the starting point, requires an analysis of the antecedents of the process. Opportunity identification has to be understood as a sequence of stages, which are affected by a previous interaction of factors. It is not a linear process; it implies an association between the entrepreneur's cognitive process and how these cognitive skills benefit from the accumulation of prior knowledge and the particular knowledge, which come from the context.

\section{Factors Influencing the Opportunity Identification Process}

Drawing on the consistency of opportunity identification as a concept, the authors investigated the basis of entrepreneurial action (Shepherd et al., 2014; Shepherd \& DeTienne, 2005; Short et al., 2010; Vaghely \& Julien, 2010). By doing so, researchers established some specific factors which exert impulse on the opportunity identification process. In opportunity identification research, authors have greatly contributed to the insights on these specific factors which include; the regulatory environment, culture and norms, prior knowledge and contextual knowledge (Khanna, 2014; Mary George et al., 2016), market incentives and networks. These factors are elaborated below. First, it is important to analyse how these factors influence the opportunity identification process and how it is possible to observe this influence.

Regulatory environment: Ma, Ding, and Yuan (2016) contend that the political capital - i.e., favourable conditions created by the host country government - influences the decision of entrepreneurs in their quest to operate in a market context. Griffiths, Gundry, 
and Kickul (2013) complement that government mechanisms regulate individual actions. Vliamos and Tzeremes (2012) show that the institutional environment has an influential impact on the entrepreneurial opportunity identification process. Institutions are the rules of the game (North, 1990), therefore to succeed, the entrepreneur's actions should be aligned to the regulatory environment in which it is located.

Culture and norms: Culture plays a strong influencing role in the entrepreneurial process (Shane, 1993; Shapero, \& Sokol, 1982; Thornton, Ribeiro-Soriano, \& Urbano, 2011). Culture differentiates one society from the other by virtue of a sustained practice or pattern or value adopted to suit the society's environment (Hofstede, 1980; Thornton et al., 2011). Nevertheless, culture is dynamic and forms the mind of the entrepreneur; therefore, its influential impact cannot be overemphasised. Hayton, George, and Zahra (2002) hypothesise a link between national culture - i.e., the aggregate adopted pattern or practice of sense making - and entrepreneurial characteristics.

Prior knowledge: This factor has been widely studied in the research in the field of opportunity identification. The authors highlight that some people can identify business opportunities due to their previously accumulated knowledge and information (Shane \& Venkataraman, 2000). The logic is that an individual is able to access information through their social network. Those individuals that neither possess knowledge nor have access will find it hard to identify opportunities. In this regard, Shane and Venkataraman (2000) divided this factor into the prior knowledge of markets, ways to serve the market, and customer problems. Our assumption is that to accumulate knowledge and access it, social capital is needed. Social capital is the cornerstone to identify opportunities. Furthermore, entrepreneurs apply their prior knowledge to sense and seize the opportunity, create the correct combination of resources and capabilities to develop the fit that matches the opportunity on markets.

Contextual knowledge: Entrepreneurs possess the ability to understand knowledge, and later apply that knowledge in a different context than the one in which the knowledge was developed (Khanna, 2015). These characteristics are mixed with entrepreneurs' social economic status within their own society, education level, and exposition to international experience (Ardichvili et al., 2003). In our perspective, the entrepreneur's ability to understand all the information collected from various sources, the sense to use that information for a particular task, and the ability to convert that information into knowledge to exploit an entrepreneurial opportunity highly depend on the entrepreneur's stock of contextual intelligence and its application (Khanna, 2015).

Incentives in the market: Keeping consistency with Schumpertian tradition (1934), Casson (1982) explains that entrepreneurial opportunity exists in the conditions of the market where a new product, service, raw material, and organising method can be introduced and sold at a price higher than the cost of their production. Shane and Venkataraman (2000) note that technological, political, social, regulatory and other changes constitute the conditions where entrepreneurs find an opportunity for enhancing their wealth by deploying the resources accessible to them in a newer way. Kirzner (1973) points out that entrepreneurial opportunity lies in the temporal and spatial inefficiencies in a given market setting. Shane and Venkataraman (2000) note that entrepreneurs will be convinced of a notion of opportunity when they believe that the expected value of entrepreneurial profit is large enough in comparison to the opportunity cost of any other alternative (Kirzner, 1973; Schumpeter, 1934). Incentives for entrepreneurs may not necessarily be economic but can 
also be in a non-economic form (Benz, 2009; Vivarelli, 1991; 2004). Both forms of incentives stem from the market and are assessed by entrepreneurs through the subjective assessment of the opportunity cost relating to choice.

Network: The idea of social capital is a meta-level concept. By applying social capital the entrepreneur connects a number of people in various locations and with different technical backgrounds (Bernardez \& Kaufman, 2013; Camps \& Marques, 2014). This happens because of the social networks which individuals develop and in which they find opportunities (Borgatti, Everett, \& Johnson, 2013). For the sake of harmony among the factors mentioned above, in our conceptual model we use the approach of the network. Networks open doors for entrepreneurs to obtain financial resources in the leveraging of their business ideas (Adler \& Kwon, 2002). This last part is quite important in the construction stage of the entrepreneurial identification process. How entrepreneurs develop ties and which type of ties is one of the main insights from the network analysis to the opportunity identification process. In this sense, the structural, the cognitive, and the relational dimensions of social capital are sources of information, knowledge, capabilities, and resources for those entrepreneurs who are able to identify opportunities (Partanen, Möller, Westerlund, Rajala, \& Rajala, 2008). How effectively entrepreneurs use their social capital is a fundamental issue in order to identify the market that they want to target. In this sense, social capital demonstrates the possibilities of the internationalisation of new ventures (Rodrigues \& Child, 2012), as well as the consolidation of products of services for international markets (Pinho, 2011). For this reason, as networks are the tangible results of social capital, networks have a strong impact on developing business for domestic and international markets thanks to the embeddedness characteristic of this factor. Entrepreneurs who apply bonding strategy can easily identify opportunities within communities and develop projects to solve those needs. This has been a fundamental case for social entrepreneurship initiatives (Tregear \& Cooper, 2016) and social enterprises (Ridley-Duff \& Bull, 2015). However, it is believed that initiatives on a global scale require that the entrepreneur has the international background or the ability to be connected internationally.

In our understanding, there is no definitive agreement in the literature about how these factors operate to benefit from the opportunity identification process. There should be a breaking point in the entrepreneur's mindset in order to offer a new benefit either to the domestic or to the international market. This breaking point is represented by the way in which the above factors interact with the opportunity identification. Whem reviewing the literature, the prominent factor which starts supporting entrepreneurs' ability to identify opportunities is entrepreneurial alertness. However, alertness receives the outcome of the interaction with the regulatory environment, culture and norms, prior knowledge and contextual intelligence, market incentives, and networks. Davidsson (2015) postulates the need to understand the context around entrepreneurs in order to see how they are able to develop a business opportunity. Our conceptual discussion contributes to this gap in the literature by elaborating a comprehensive understanding of the opportunity identification from the contextual perspective. Particularly, this comprehensive conceptual framework is shown in Figure 1. 


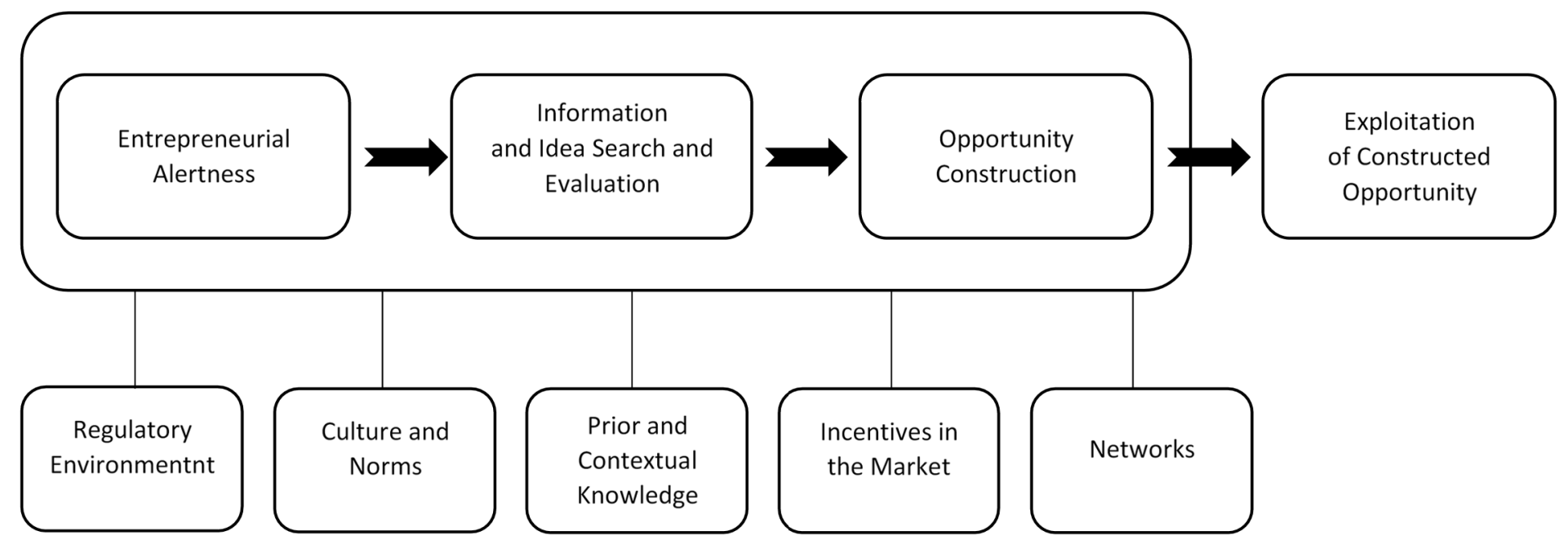

Figure 1. Conceptualisation of the entrepreneurial opportunity identification process Source: own study. 


\section{Defining the Domestic and International Context}

A business venture may target the domestic or international contexts. Context is defined in terms of the amount and types of resources, actors competing for resources, the activities, aims and requirements of firms and institutions (Håkansson \& Snehota, 1997; Keating \& McLoughlin, 2010; Schoonhoven, Eisenhardt, \& Lyman, 1990). For a consistent thought, context is a composition of major factors, such as the regulatory environment, culture and norms, prior knowledge, market incentives and networks. In other words, the entrepreneurial process is influenced by the institutional, social and economic contexts (Hayton et al., 2002; Leff, 1979). Seen in this way, the entrepreneurial process is embedded in a context which spans in both domestic and international contexts. By the domestic context, we mean the geographic location of entrepreneurs where they have accustomed themselves for long periods and have actively shaped that environment. By the international context, we refer to the new geographic location the entrepreneur intends to penetrate with his or her entrepreneurial ideas. We therefore argue that the entrepreneurial identification process is subject to similar and varying tendencies in both domestic and international contexts.

\section{The Regulatory Environment in the Domestic and International Context}

From the familiarity point of view, entrepreneurs in the domestic context are more equipped to adapt to bottlenecks and conflict. In other words, entrepreneurs are more flexible in the domestic context than in the international context. This is explained by the fact that in the domestic context they are deeply embedded and as such understand "dos and don'ts". Entrepreneurs not embedded in the international context have a thin cushion for uncertainty, bottleneck, and conflict.

\section{Culture and Norms in the Domestic and International Context}

Entrepreneurs in the domestic context are spontaneous to making sense of the established practices, patterns or values. Additionally, they will demonstrate identical interpretations of accepted norms. In other words, another entrepreneur from the same domestic context can replicate similar interpretation and sense-making. On the other hand, entrepreneurs will culturally switch to fit in the international context. That is to say, that they will invest motivated efforts in interpretation and adaptation to understand the international context.

\section{Prior and Contextual Knowledge in the Domestic and International Context}

Entrepreneurs capture and develop knowledge through various sources and activities during their professional life. In the case of the domestic context, the formal education process is relevant in terms of technical knowledge. Specifically, entrepreneurs develop the abilities to process, classify and codify information, which they turn into knowledge. In the case of a domestic market, entrepreneurs possess a natural amount of contextual knowledge through their strong embeddedness to the domestic context. The difference in entrepreneurs' ability to search and identify the opportunity in the domestic market is strongly explained by their accesses and ties to different formal and informal institutions and networks. By contrast, the international context demands a high level of awareness and recognition of opportunities for entrepreneurs. They need to combine various sources of information as well as knowledge. In this regard, involvement in international contexts, such as 
cultural exchanges, study abroad, language skills, and work experience are crucial to exploit opportunities. Therefore, an international context represents a challenging as well as a valuable context where entrepreneurs constantly have to improve their abilities.

\section{Incentives in the Domestic and International Context}

In the domestic context, entrepreneurs have high predictability relating to interpretation and changes in the parameters. Knowing tendencies and current patterns in domestic markets, entrepreneurs are able to anticipate opportunities. This is reflected in the case of offering innovative products. Likewise, policies and social-economic conditions can play a role in the identification of opportunities. In the context of international markets, entrepreneurs have lower predictability and tolerance due to uncertainty relating to such parameters. Global economic crisis, new regulations, regional conflicts, or changes of governments reduce entrepreneurs' abilities to predict, act and operate on international markets.

\section{Networks in the Domestic and International Market}

The concept of networks here connotes both social and business networks. While entrepreneurs encapsulate their relationships with other individuals through using social networks (Guercini \& Ranfagni, 2016), they use the business network to develop relationships with other firms (Guercini \& Ranfagni, 2016; Håkansson, Ford, \& Gadde, 2009). Entrepreneurs belong to both networks at any point in time because they are social beings and at the same time business-oriented. In the domestic context, entrepreneurs rely more on both social and business networks because they are embedded in these networks at close range. In the international context, the entrepreneurs rely more on business networks than social networks. This is argued from the perspective that the boundaries of business networks are not clearly defined (Snehota, 2004). Indeed, there are differences in domestic and international markets, but Forsgren (2016) argues that the difference should be seen from the firm's business context and not the country border per se. Therefore, entrepreneurs will draw on business networks as a buffer to mitigate uncertainties on the international market. Table 1 shows elements of domestic and international contexts.

Table 1. Juxtaposing the domestic and international context

\begin{tabular}{|l|l|l|}
\hline \multicolumn{1}{|c|}{ Factors } & \multicolumn{1}{|c|}{ Domestic context } & \multicolumn{1}{c|}{ International context } \\
\hline $\begin{array}{l}\text { Regulatory en- } \\
\text { vironment }\end{array}$ & $\begin{array}{l}\text { The entrepreneur is more equipped to } \\
\text { adapt to bottlenecks and conflict }\end{array}$ & $\begin{array}{l}\text { The entrepreneur has a thin cushion for un- } \\
\text { certainty, bottleneck, and conflict }\end{array}$ \\
\hline $\begin{array}{l}\text { Culture and } \\
\text { norms }\end{array}$ & $\begin{array}{l}\text { More spontaneous and identical in the in- } \\
\text { terpretations of meanings and conflicts. } \\
\text { Trust is norm-based }\end{array}$ & $\begin{array}{l}\text { Invest motivated efforts in interpretation } \\
\text { and adaptation. Trust is highly institution- } \\
\text { based }\end{array}$ \\
\hline $\begin{array}{l}\text { Prior and con- } \\
\text { textual } \\
\text { knowledge }\end{array}$ & $\begin{array}{l}\text { Significant part of such knowledge base } \\
\text { builds up through institutional and social } \\
\text { embeddedness }\end{array}$ & $\begin{array}{l}\text { Entrepreneurs actively and persistently in- } \\
\text { vest in the searching of information to } \\
\text { achieve international markets }\end{array}$ \\
\hline $\begin{array}{l}\text { Incentives on } \\
\text { the market }\end{array}$ & $\begin{array}{l}\text { Higher predictability relating to interpre- } \\
\text { tations and changes in the parameters }\end{array}$ & $\begin{array}{l}\text { Lower predictability and lower tolerance re- } \\
\text { lating to uncertainty in the parameters }\end{array}$ \\
\hline Networks & $\begin{array}{l}\text { The entrepreneur relies on both social } \\
\text { and business networks }\end{array}$ & $\begin{array}{l}\text { The entrepreneur relies largely on business } \\
\text { networks to mitigate uncertainties }\end{array}$ \\
\hline
\end{tabular}

Source: own study. 


\section{Factors Influencing the Entrepreneurial Process in the Domestic and International Context}

Table 2 demonstrates comparative intensity of the roles of the factors (regulatory environment, culture and norms, prior and contextual knowledge, incentives in the market and networks) in the process of entrepreneurial opportunity identification in domestic and international context.

Table 2. Intensity of the roles of the factors in the phases of entrepreneurial opportunity identification process in the domestic and international context

\begin{tabular}{|l|c|c|c|c|c|c|}
\hline \multirow{2}{*}{ Factors } & \multicolumn{3}{c|}{ Domestic Context } & \multicolumn{3}{c|}{ International Context } \\
\cline { 2 - 7 } & Alertness & Search & Construction & Alertness & Search & Construction \\
\hline Regulatory environment & Low & Medium & High & High & High & Low \\
\hline Culture and norms & Low & Low & High & High & High & Low \\
\hline Prior and contextual knowledge & Low & Medium & Low & High & Medium & High \\
\hline Incentives in the market & Low & Medium & High & High & High & Low \\
\hline Networks & Low & Low & High & High & High & High \\
\hline
\end{tabular}

Source: own study.

\section{The Role of the Intensity of the Factors in the 'alertness phase'}

The entrepreneurial active search leading to alertness is expected to be lower in the domestic context due to the entrepreneur's higher degree of embeddedness to the domestic regulations. The degree of alertness to international opportunities will be high, in that entrepreneurs are constantly scouting for international opportunities which are not available in the domestic context but in consonance with the host country regulatory environment.

Moreover, the culture and norms play a role in the pressure to conform. Entrepreneurs are aware of their domestic context and have a spontaneous response to the dictates of culture and norms. In this way, a natural tendency to conform reduces sharp alertness to sense an entrepreneurial opportunity. When entrepreneurs seek to operate in an international context, their limited knowledge of the new context leads them to build a response to the culture and norms of the host market. A created tendency to conform gives entrepreneurs the edge to increase their alertness to sense an entrepreneurial opportunity.

In the domestic context, entrepreneurs are endowed with a natural amount of knowledge because they are aware of the different sources from which this knowledge emerges. Given the argument, entrepreneurs' alertness will be low in the domestic context because prior and contextual knowledge are somewhat given. When entrepreneurs seek to operate in an international context, their unawareness of different sources of contextual knowledge in the host market leads them to proactively increase their alertness to fish out entrepreneurial opportunities available.

Similarly, incentives on the market are influenced by factors such as the regulatory environment, culture and norms, prior and contextual knowledge, as well as the available networks. Therefore, the pressure to conform in order to meet the criteria to acquire incentives is spread across both the domestic and international context. In relation to the degree of alertness to sense an opportunity, this will be low in the domestic context, because entrepreneurs are accustomed to these factors and can operate with or without 
incentives in the market. Conversely, entrepreneurs will have a high sense of alertness when they operate in an international context because they are not habituated to various factors on the host market. Entrepreneurs will scan for such incentives, which will motivate them to pursue an opportunity in the international context.

Networks have the tendency to weaken the alertness of entrepreneurs in the domestic context because there is a greater likelihood that the network may not produce newness as far as bonding social capital is concerned. In the international context, entrepreneurs will be highly alert because they are not deeply embedded; therefore, they are capable of employing bridging and linking social capital, which will make them alert in their quest for an opportunity. In the nutshell, when t entrepreneurs are familiar with the domestic context, their alertness will be low as compared to the international context.

\section{The Role of the Intensity of Factors in the 'search phase'}

Opportunities can be searched through systematic and non-systematic means (Ardichvili et al., 2003; Timmons, Muzyka, Stevenson, \& Bygrave, 1987). In our understanding, a systematic search reflects careful planning. A non-systematic search reflects a loose approach to preparation. In the regulatory environment of the domestic context, entrepreneurs employ both systematic and non-systematic means of opportunity searching reflecting a medium level of intensity. This is because entrepreneurs can adapt to bottlenecks and conflicts, hence need less to undertake systematic means for opportunity searching. Nevertheless, the regulatory environment is not static; thus, entrepreneurs in the domestic context may employ systematic search when the regulatory environment brings about changes, which promote newness. Entrepreneurs seeking opportunities in an international context will employ a systematic search, reflecting a high level of intensity. This relates to the fact that entrepreneurs will carefully align their opportunity search to the regulatory environment to which they are not accustomed.

As far as culture and norms are concerned, entrepreneurs will employ non-systematic means to search of an opportunity in the domestic context, hence a low level of intensity for opportunity search. Our argument is based on the fact that entrepreneurs in the domestic context are not prone to bear liability for foreignness and outsidership (Forsgren, 2016; Johanson \& Vahlne, 2009) because the need to invest motivated efforts in the search for an opportunity is low. When such entrepreneurs decide to expand operations to an international context, they employ systematic means of opportunity search, reflecting a high level of intensity for opportunity search. This is because they are liable for foreignness and are aware of their outsidership when faced with the culture and norms of the host market. Therefore, they put in motivated efforts to search for opportunities.

Entrepreneurs who have prior and contextual knowledge will employ both non- systematic and systematic means to search for an opportunity. Our argument here is that if entrepreneurs' existing knowledge does not offer any clue as leading to a new opportunity, then non-systematic means to search for an opportunity will be employed. However, if entrepreneurs' existing knowledge is continuously improved, it has the tendency to bring about newness. Since newness inherently breeds opportunities, entrepreneurs will scrutinise it through systematic means. The same is true for entrepreneurs seeking to operate in an international context. If they have prior and contextual knowledge about the host market, their search, in the beginning, will be non-systematic. However, their approach to opportunity search will be systematic when the existing knowledge is less useful during international entry. 
Much the same as the factors of the regulatory environment and prior and contextual knowledge, incentives on the market affect the intensity of search whether in the domestic or international context. In the domestic context, entrepreneurs are aware of incentives, which facilitate or inhibit the intensity of opportunity search. Entrepreneurs in the domestic context know their market and will employ non-systematic means to search for an opportunity when the incentives on the market are at a close grasp. However, they will employ systematic means if the incentives are provided by the market exclusively. This, of course, will guide them to avoid searching for opportunities that will not be realisable. In the international context, entrepreneurs will employ systematic means to search for opportunities because incentives on the host market are available to them only when they proactively acquaint themselves, hence the systematic means to search for an opportunity.

Here again, networks may weaken the intensity to search for an entrepreneurial opportunity. In the domestic context, there is a tendency that entrepreneurs' social capital and business networks are intertwined and difficult to separate. Therefore, we argue that entrepreneurs' search for opportunity is low in the domestic context because bonding social capital and business networks may not produce newness that will engender the search for an opportunity based on systematic means. Entrepreneurs seeking to operate in the international context will rely on business networks, which spans across borders other than social capital, which is geographically bound to the entrepreneurs' domestic context. It suffices to say that business networks have formal structures devoid of personal conflict. In this way, the opportunity search will rely on systematic means.

\section{The Role of the Intensity of the Factors in the 'construction phase'}

We further argue that the speed at which entrepreneurs mentally construct an opportunity is higher in the domestic context than in the international context, given more informed and accustomed institutional conditions. Cognitive processes are created in consonance with the environment an entrepreneur identifies with. Entrepreneurs scan and pick appropriate information needed from the immediate environment and process them to produce a mental frame of the opportunity. Due to the fact, they are closer to the domestic context than in the international context, mental constructing the opportunity is much clearer. Both culture and norms, as well as the incentives on the market, shape the cognitive process of the entrepreneur in the domestic context because he picks information from the economic environment and mentally constructs the opportunity for exploitation. On the other hand, entrepreneurs seek to internationalise the possessed limited knowledge of culture and norms, and the incentives in the foreign context. Therefore, their mental construction of the image of the international opportunities is limited.

\section{CONCLUSIONS}

Studying the IE theoretical framework, we establish the main differences between the opportunity identification processes according to domestic or international markets. We propose a matrix in order to identify how entrepreneurs adapt their mindset to find an opportunity. Entrepreneurs' ability to search, identify and exploit business opportunities deal with framework conditions as well as with personality traits. However, some grey areas of the opportunity identification process need further research. For example, it is important 
to examine the impact of culture and institutions in the configuration of the entrepreneur's cognition processes. Particularly, how culture and institutions can be enablers or constraints for knowledge management by entrepreneurs who are building new ventures. It is necessary to investigate the role of social networks. Specifically, how social networks facilitate the mobilisation of resources by entrepreneurs on international markets. As a relevant future research theme, it is important to understand which approach entrepreneurs follow in order to exploit an opportunity. From the practical point of view, it is relevant for entrepreneurs to identify the resources, which are involved in the entrepreneurial action in order to exploit an opportunity in the international context. Moreover, capabilities and resources perspective can be additional research trends in the entrepreneurial opportunity identification. Practitioners can ensure efforts to foster the interaction of entrepreneurs with governmental institutions and programmes. Particularly, the promotion of entrepreneurship through policies should include instruments for identifying opportunities on both domestic and international markets. The conceptual implication of this paper is summarised as an invitation for scholars to apply the conceptual matrix of factors influencing the entrepreneurial identification process according to the market context. It will be an interesting discussion to explore the changing mindset of entrepreneurs when they deal with various markets context at the same time.

\section{REFERENCES}

Adler, P.S., \& Kwon, S.W. (2002). Social Capital: Prospects for a New Concept. The Academy of Management Review, 27(1), 17-40.

Allen, I. (2016). International Entrepreneurship Theory: Past, Present and Way Forward. Entrepreneurial Business and Economics Review, 4(4), 93-103. https://doi.org/10.15678/EBER.2016.040406

Alvarez, S.A., \& Barney, J.B. (2007). Discovery and Creation: Alternative Theories of Entrepreneurial Action. Revista Organizações em Contexto, 3(6), 123-152. doi: https://doi.org/10.15603/1982-8756/roc.v3n6p123-152

Alvarez, S.A., Barney, J.B., \& Anderson, P. (2013). Forming and Exploiting Opportunities: The Implications of Discovery and Creation Processes for Entrepreneurial and Organizational Research. Organization Science, 24(1), 301-317. doi: https://doi.org/10.1287/orsc.1110.0727

Anderson, B.S., Kreiser, P.M., Kuratko, D.F., Hornsby, J.S., \& Eshima, Y. (2015). Reconceptualizing entrepreneurial orientation. Strategic Management Journal, 36(10), 1579-1596. doi: https://doi.org/10.1002/smj.2298

Andersson, S., \& Evers, N. (2015). International opportunity recognition in international new ventures-a dynamic managerial capabilities perspective. Journal of International Entrepreneurship, 13(3), 260-276. doi: https://doi.org/10.1007/s10843-015-0149-5

Ardichvili, A., Cardozo, R., \& Ray, S. (2003). A theory of entrepreneurial opportunity identification and development. Journal of Business Venturing, 18(1), 105-123. doi: https://doi.org/10.1016/S0883-9026(01)00068-4

Benz, M. (2009). Entrepreneurship as a non-profit-seeking activity. International Entrepreneurship and Management Journal, 5(1), 23-44. doi: https://doi.org/10.1007/s11365-006-0031-y

Bernardez, M.L., \& Kaufman, R. (2013). Turning Social Capital Into Social Performance: Three Case Studies and a New Framework for Value Creation. Performance Improvement, 52(5), 5-18. doi: https://doi.org/10.1002/pfi.21345 
Borgatti, S.P., Everett, M.G., \& Johnson, J.C. (2013). Analyzing Social Networks. Thousand Oaks: Sage Publishing.

Busenitz, L.W., Plummer, L.A., Klotz, A.C., Shahzad, A., \& Rhoads, K. (2014). Entrepreneurship research (1985-2009) and the emergence of opportunities. Entrepreneurship, Theory and Practice: $E T$ \& $P, 38(5), 981-1000$.

Camps, S., \& Marques, P. (2014). Exploring how social capital facilitates innovation: The role of innovation enablers. Technological Forecasting and Social Change, 88, 325-348. doi: https://doi.org/10.1016/j.techfore.2013.10.008

Casson, M. (1982). The entrepreneur: An economic theory/Mark Casson (2nd ed.). Cheltenham, UK: Edward Elgar.

Chandra, Y., Styles, C., \& Wilkinson, I. (2009). The recognition of first time international entrepreneurial opportunities. International Marketing Review, 26(1), 30-61. doi: https://doi.org/10.1108/02651330910933195

Chandra, Y., Styles, C., \& Wilkinson, I.F. (2015). Opportunity portfolio: Moving beyond single opportunity explanations in international entrepreneurship research. Asia Pacific Journal of Management, 32(1), 199-228. doi: https://doi.org/10.1007/s10490-014-9400-1

Coviello, N.E., McDougall, P.P., \& Oviatt, B.M. (2011). The emergence, advance and future of international entrepreneurship research - An introduction to the special forum. Journal of Business Venturing, 26(6), 625-631. doi: https://doi.org/10.1016/j.jbusvent.2011.07.002

Davidsson, P. (2015). Entrepreneurial opportunities and the entrepreneurship nexus: A re-conceptualization. Journal of Business Venturing, 30(5), 674-695. doi: https://doi.org/10.1016/j.jbusvent.2015.01.002

Dimitratos, P., Buck, T., Fletcher, M., \& Li, N. (2016). The motivation of international entrepreneurship: The case of Chinese transnational entrepreneurs. International Business Review, 25(5), 1103-1113. doi: https://doi.org/10.1016/j.ibusrev.2016.01.012

Dornberger, U., \& Suvelza, A. (2012). Managing the Fuzzy Front-End of Innovation. Leipzig: the Leipzig University.

Eckhardt, J.T., \& Shane, S.A. (2003). Opportunities and Entrepreneurship. Journal of Management, 29(3), 333-349. doi: https://doi.org/10.1016/S0149-2063(02)00225-8

Fiet, J.O. (2007). A Prescriptive Analysis of Search and Discovery. Journal of Management Studies, 44(4), 592-611. doi: https://doi.org/10.1111/j.1467-6486.2006.00671.x

Forsgren, M. (2016). A note on the revisited Uppsala internationalization process model - the implications of business networks and entrepreneurship. Journal of International Business Studies, 47(9), 1135-1144. doi: https://doi.org/10.1057/s41267-016-0014-3

Gaglio, C.M., \& Katz, J.A. (2001). The Psychological Basis of Opportunity Identification: Entrepreneurial Alertness. Small Business Economics, 16(2), 95-111. doi: https://doi.org/10.1023/A:1011132102464

Greblikaite, J., Sroka, W., \& Gerulaitiene, N. (2016). Involving Young People in Polish and Lithuanian Social Enterprises by Fostering Entrepreneurial Skills and Abilities as Entrepreneurial Opportunity at University. Entrepreneurial Business and Economics Review, 4(3), 131-152. doi: https://doi.org/10.15678/EBER.2016.040310

Grégoire, D.A., \& Shepherd, D.A. (2012). Technology-market combinations and the identification of entrepreneurial opportunities: An investigation of the opportunity-individual nexus. Academy of Management Journal, 55(4), 753-785.

Griffiths, M.D., Gundry, L.K., \& Kickul, J.R. (2013). The socio-political, economic, and cultural determinants of social entrepreneurship activity. Journal of Small Business and Enterprise Development, 20(2), 341-357. doi: https://doi.org/10.1108/14626001311326761 
Guercini, S., \& Ranfagni, S. (2016). Conviviality behavior in entrepreneurial communities and business networks. Journal of Business Research, 69(2), 770-776. doi: https://doi.org/10.1016/j.jbusres.2015.07.013

Håkansson, H., Ford, D., \& Gadde, L.E. (2009). Business in networks. Hoboken, N.J.: Wiley; Chichester: John Wiley [distributor].

Håkansson, H., \& Snehota, I. (1997). Developing relationships in business networks. London: International Thomson Business Press.

Hayton, J.C., George, G., \& Zahra, S.A. (2002). National Culture and Entrepreneurship: A Review of Behavioral Research. Entrepreneurship Theory and Practice, 33-52. Retrieved on March 27, 2017 from http://ink.library.smu.edu.sg/lkcsb_research/4642

Heilbrunn, S. (2010). Entrepreneurial opportunities in changing communities. Journal of Small Business and Enterprise Development, 17(2), 247-259. https://doi.org/10.1108/14626001011041247

Hernández, R.A., Martínez Piva, J.M., \& Mulder, N. (2014). Global value chains and world trade: Prospects and challenges for Latin America. ECLAC Books: Vol. 127. Santiago: Economic Commission for Latin America and the Caribbean (ECLAC).

Hofstede, G. (1980). Motivation, leadership, and organization: Do American theories apply abroad?. Organizational Dynamics, 9(1), 42-63. doi: https://doi.org/10.1016/0090-2616(80)90013-3

Johanson, J., \& Vahlne, J.E. (2009). The Uppsala internationalization process model revisited: From liability of foreignness to liability of outsidership. Journal of International Business Studies, 40(9), 1411-1431. doi: https://doi.org/10.1057/jibs.2009.24

Jones, M.V., Coviello, N., \& Tang, Y.K. (2011). International Entrepreneurship research (1989-2009): A domain ontology and thematic analysis. Journal of Business Venturing, 26(6), 632-659. doi: https://doi.org/10.1016/j.jbusvent.2011.04.001

Keating, A., \& McLoughlin, D. (2010). The entrepreneurial imagination and the impact of context on the development of a new venture. Industrial Marketing Management, 39(6), 996-1009. doi: https://doi.org/10.1016/j.indmarman.2010.06.019

Khanna, T. (2014). Contextual intelligence. Harvard Business Review, 92(9), 58-68. Retrieved on March 17, 2017 from https://hbr.org/2014/09/contextual-intelligence

Khanna, T. (2015). A Case for Contextual Intelligence. Management International Review, 55(2), 181190. doi: https://doi.org/10.1007/s11575-015-0241-z

Kirzner, I.M. (1973). Competition and entrepreneurship (7. Dr). Chicago: University of Chicago Press.

Leff, N.H. (1979). Entrepreneurship and Economic Development: The Problem Revisited. Journal of Economic Literature, 17(1), 46-64.

Ma, X., Ding, Z., \& Yuan, L. (2016). Subnational institutions, political capital, and the internationalization of entrepreneurial firms in emerging economies. Journal of World Business, 51(5), 843854. doi: https://doi.org/10.1016/j.jwb.2016.07.004

Mainela, T., Puhakka, V., \& Servais, P. (2014). The Concept of International Opportunity in International Entrepreneurship: A Review and a Research Agenda. International Journal of Management Reviews, 16(1), 105-129. doi: https://doi.org/10.1111/ijmr.12011

Mary George, N., Parida, V., Lahti, T., \& Wincent, J. (2016). A systematic literature review of entrepreneurial opportunity recognition: Insights on influencing factors. International Entrepreneurship and Management Journal, 12(2), 309-350. doi: https://doi.org/10.1007/s11365-014-0347-y

McDougall, P.P., \& Oviatt, B.M. (2000). International Entrepreneurship: The Intersection of two research paths. Academy of Management Journal, 43(5), 902-906. doi: https://doi.org/10.2307/1556418

McMullen, J.S., \& Dimov, D. (2013). Time and the Entrepreneurial Journey: The Problems and Promise of Studying Entrepreneurship as a Process. Journal of management studies, n/a-n/a. doi: https://doi.org/10.1111/joms.12049 
Muzychenko, O., \& Liesch, P.W. (2015). International opportunity identification in the internationalisation of the firm. Journal of World Business, 50(4), 704-717. doi: https://doi.org/10.1016/j.jwb.2014.12.001

Ngo, V.D., Janssen, F., \& Falize, M. (2016). An incentive-based model of international entrepreneurship in emerging and transition economies. Journal of International Entrepreneurship, 14(1), 5274. doi: https://doi.org/10.1007/s10843-016-0165-0

North, D.C. (1990). Institutions, institutional change and economic performance. Political economy of institutions and decisions. Cambridge: Cambridge University Press.

OECD. (2016). OECD Economic Outlook: Paris: OECD Publishing.

Oyson, M.J., \& Whittaker, H. (2015). Entrepreneurial cognition and behavior in the discovery and creation of international opportunities. Journal of International Entrepreneurship, 13(3), 303336. doi: https://doi.org/10.1007/s10843-015-0156-6

Partanen, J., Möller, K., Westerlund, M., Rajala, R., \& Rajala, A. (2008). Social capital in the growth of science-and-technology-based SMEs. Industrial Marketing Management, 37(5), 513-522. doi: https://doi.org/10.1016/j.indmarman.2007.09.012

Pinho, J.C.M. (2011). Social capital and dynamic capabilities in international performance of SMEs. Journal of Strategy and Management, 4(4), 404-421. doi: https://doi.org/10.1108/17554251111181034

Ridley-Duff, R., \& Bull, M. (2015). Understanding social enterprise: Theory and practice / Rory RidleyDuff and Mike Bull (2nd ed.). Thousand Oaks: Sage Publishing.

Rodrigues, S.B., \& Child, J. (2012). Building social capital for internationalization. Revista de Administração Contemporânea, 16(1), 23-38. doi: https://doi.org/10.1590/S1415-65552012000100003

Sambasivan, M., Abdul, M., \& Yusop, Y. (2009). Impact of personal qualities and management skills of entrepreneurs on venture performance in Malaysia: Opportunity recognition skills as a mediating factor. Technovation, 29(11), 798-805. doi: https://doi.org/10.1016/j.technovation.2009.04.002

Sarasvathy, S.D. (2001). Causation and Effectuation: Toward a Theoretical Shift from Economic Inevitability to Entrepreneurial Contingency. The Academy of Management Review, 26(2), 243. doi: https://doi.org/10.2307/259121

Schoonhoven, C.B., Eisenhardt, K.M., \& Lyman, K. (1990). Speeding Products to Market: Waiting Time to First Product Introduction in New Firms. Administrative Science Quarterly, 35(1), 177. doi: https://doi.org/10.2307/2393555

Schumpeter, J. (1934). Capitalism, Socialism, and Democracy. New York: Harper \& Row.

Schweizer, R., Vahlne, J.E., \& Johanson, J. (2010). Internationalization as an entrepreneurial process. Journal of International Entrepreneurship, 8(4), 343-370. doi: https://doi.org/10.1007/s10843-010-0064-8

Shane, S., \& Venkataraman, S. (2000). The promise of entrepreneurship as a field of research. Academy of Management Review, 25(1), 217-226. doi: https://doi.org/10.5465/AMR.2000.2791611

Shane, S. (1993). Cultural influences on national rates of innovation. Journal of Business Venturing, 8(1), 59-73. doi: https://doi.org/10.1016/0883-9026(93)90011-S

Shane, S. (2000). Prior Knowledge and the Discovery of Entrepreneurial Opportunities. Organization Science, 11(4), 448-469. doi: https://doi.org/10.1287/orsc.11.4.448.14602

Shapero, A., \& Sokol, L. (1982). The Social Dimensions of Entrepreneurship. Encyclopedia of Entrepreneurship, 1, 72-90.

Shepherd, D.A., \& DeTienne, D.R. (2005). Prior Knowledge, Potential Financial Reward, and Opportunity Identification. Entrepreneurship Theory and Practice, 29(1), 91-112. doi: https://doi.org/10.1111/j.1540-6520.2005.00071.x 
Shepherd, D.A., Williams, T.A., \& Patzelt, H. (2014). Thinking About Entrepreneurial Decision Making Review and Research Agenda. Journal of Management, 41(1), 11-46. doi: https://doi.org/10.1177/0149206314541153

Short, J.C., Ketchen, D.J., Shook, C.L., \& Ireland, R.D. (2010). The Concept of “Opportunity" in Entrepreneurship Research: Past Accomplishments and Future Challenges. Journal of Management, 36(1), 40-65. doi: https://doi.org/10.1177/0149206309342746

Snehota, I. (2004). Perspectives and theories of market. In H. Håkansson, D. Harrison \& A. Waluszewski (Eds.), Rethinking Marketing. Developing a New Understanding of Markets (pp. 15-32). Chichester: Wiley.

Thornton, P.H., Ribeiro-Soriano, D., \& Urbano, D. (2011). Socio-cultural factors and entrepreneurial activity: An overview. International Small Business Journal, 29(2), 118. doi: https://doi.org/10.1177/0266242610391930

Timmons, J., Muzyka, D., Stevenson, H., \& Bygrave, W. (1987). Opportunity recognition: the core of entrepreneurship. In N. Churchill \& et al. (Eds.), Frontiers of Entrepreneurshio Research. Babson Park, MA: Center for Entrepreneurial Studies, Babson College.

Tregear, A., \& Cooper, S. (2016). Embeddedness, social capital and learning in rural areas: The case of producer cooperatives. Journal of Rural Studies, 44, 101-110. doi: https://doi.org/10.1016/j.jrurstud.2016.01.011

Vaghely, I.P., \& Julien, P.A. (2010). Are opportunities recognized or constructed?. Journal of Business Venturing, 25(1), 73-86. doi: https://doi.org/10.1016/j.jbusvent.2008.06.004

Vivarelli, M. (1991). The birth of new enterprises. Small Business Economics, 3(3), 215-223. doi: https://doi.org/10.1007/BF00400026

Vivarelli, M. (2004). Are All the Potential Entrepreneurs So Good?. Small Business Economics, 23(1), 41-49. doi: https://doi.org/10.1023/B:SBEJ.0000026023.11752.a9

Vliamos, S.J., \& Tzeremes, N.G. (2012). Factors Influencing Entrepreneurial Process and Firm StartUps: Evidence from Central Greece. Journal of the Knowledge Economy, 3(3), 250-264. doi: https://doi.org/10.1007/s13132-011-0043-x

Webb, J.W., Ireland, R.D., Hitt, M.A., Kistruck, G.M., \& Tihanyi, L. (2011). Where is the opportunity without the customer?: An integration of marketing activities, the entrepreneurship process, and institutional theory. Journal of the Academy of Marketing Science, 39(4), 537-554. doi: https://doi.org/10.1007/s11747-010-0237-y

Wood, M.S., \& McKinley, W. (2010). The production of entrepreneurial opportunity: a constructivist perspective. Strategic Entrepreneurship Journal, 4(1), 66-84. doi: https://doi.org/10.1002/sej.83 


\section{Authors}

The contribution share of authors is equal and amounted to $25 \%$ each of them.

\section{Yonni Angel Cuero Acosta}

Bachelor of Finance and International Business (University of Santiago de Cali, Colombia); Master in International Economics (University of Havana, Cuba); PhD in Small Enterprises Development (Leipzig University, Germany). His research interests include international entrepreneurship, the development of technology-intensive suppliers in emerging economies. Correspondence to: Dr. Yonni Angel Cuero Acosta, Leipzig University, International SEPT Program, Ritterstr. 9-13, 04109 Leipzig, Germany, e-mail: yonni.cuero@uni-leipzig.de

\section{Richard Adu-Gyamfi}

Bachelor degree in Publishing Studies (Kwame Nkrumah University of Science and Technology (KNUST), Kumasi, Ghana); MBA in SME Development (Leipzig University, Germany); PhD in International Business and Entrepreneurship from the Leipzig University (Germany). His research interests include international business and entrepreneurship from developing country context, value chains, export processing zones, linkages and networks and knowledge transfer.

Correspondence to: Dr. Richard Adu-Gyamfi, Leipzig University, International SEPT Program, Ritterstr. 9-13, 04109 Leipzig, Germany, e-mail: richard.adu-gyamfi@uni-leipzig.de

\section{Md. Noor Un Nabi}

Professor in Business Administration at Khulna University in Bangladesh and currently Visiting Professor in the International Small Enterprise Promotion and Training (SEPT) Program at Leipzig University in Germany. He regularly teaches in MBA and Executive-MBA Programmes at universities in Bangladesh, Vietnam and Germany. His research interests include strategy and the capabilities for the internationalisation of firms from the developing and emerging market countries, international entrepreneurship. Correspondence to: Prof. Dr. Md. Noor Un Nabi, Leipzig University, International SEPT Program, Ritterstr. 9-13, 04109 Leipzig, Germany, e-mail: noor@uni-leipzig.de

\section{Utz Dornberger}

Director of the International SEPT Program at Leipzig University (Germany), Director of Start-up initiative Self-Management Initiative Leipzig (SMILE) at Leipzig University, Director of MBA Programme at Hanoi University of Science and Technology (HUST) and Vietnamese-German University (VGU) and Lecturer on innovation management and entrepreneurship promotion, as well as head of the unit of Entrepreneurship and Innovation for Development Cooperation at Fraunhofer Center for International Management and Knowledge Economy (IMW) (Leipzig, Germany). His research interests include SME promotion, SME support, innovation management, international marketing, R\&D Co-operation.

Correspondence to: Prof. Dr. Utz Dornberger, Leipzig University, International SEPT Program, Ritterstr. 9-13, 04109 Leipzig, Germany, e-mail: dornberger@uni-leipzig.de

\section{Copyright and License}

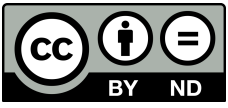

This article is published under the terms of the Creative Commons

Attribution - NoDerivs (CC BY- ND 4.0) License http://creativecommons.org/licenses/by-nd/4.0/

\footnotetext{
Published by the Centre for Strategic and International Entrepreneurship - Krakow, Poland
} 
